Brazilian Journal

of Chemical

\title{
EFFECTS OF DRYING TEMPERATURE AND RELATIVE HUMIDITY ON THE MECHANICAL PROPERTIES OF AMARANTH FLOUR FILMS PLASTICIZED WITH GLYCEROL
}

\author{
D. Tapia-Blácido ${ }^{1}$, P. J. Sobral ${ }^{2}$ and F. C. Menegalli ${ }^{1}$ \\ ${ }^{1}$ Food Engineering Department, FEA, UNICAMP, Fax (019) 3788-4027, \\ 13083-970, Campinas - SP, Brazil. \\ E-mail:drtapia@fea.unicamp.br, \\ E-mail: fcm@fea.unicamp.br \\ ${ }^{2}$ Food Engineering Department, FZEA-USP, PO Box 23, \\ 13630-000, Pirassununga - SP, Brazil. \\ E-mail: pjsobral@usp.br
}

(Received: October 20, 2004 ; Accepted: February 12, 2005)

\begin{abstract}
Biofilms are made of biopolymers. In the casting technique, biofilms are obtained by the drying of a polymer suspension in the final stage of processing. The aim of the present paper was to analyze the effect of this drying process on the mechanical properties of films produced with amaranth flour. Variables considered include glycerol content (30, 35 and 40\%, g/g dry flour) and air-drying conditions (air temperatures of 30,40 and $50^{\circ} \mathrm{C}$ and relative humidities of 40,55 and $70 \%$ ). As amaranth flour films constitute a complex mixture of amylopectin and amylose as well as native protein and lipid, certain unexpected results were obtained. The toughest films were obtained at the lowest temperature and the lowest relative humidity $\left(30^{\circ} \mathrm{C}, 40 \%\right)$.

Keywords: Amaranth; Edible film; Film drying.
\end{abstract}

\section{INTRODUCTION}

Edible films and coatings offer alternatives to synthetic packaging materials. They have attracted considerable interest in recent years for different reasons, such as consumer pressure in relation to health, food quality, convenience and reduction in packaging waste. The characteristics of biofilms are closely_related to the specific macromolecules involved in the biofilm formulation and they are always dependent on the process of biofilm production as well. In the casting technique, the biofilm is obtained by the drying of a complex solution consisting of a polymer, a volatile solvent (and sometimes a nonvolatile one) and occasionally a lipid phase. The effect of given drying conditions depends on various characteristics of the raw material, such as a pre-existing gel phase or the occurrence of thermal gelation during drying. Moreover, various phenomena, such as the transition from an amorphous to a vitreous phase, the appearance of phase separation (thermodynamic incompatibility) and crystallization, may occur. The interaction between the physicochemical nature of biopolymers and drying conditions is quite important. Little research on starch and protein raw materials can be cited. The effect of air-drying temperature and relative humidity on the mechanical and barrier properties of amylopectin and amylose films was studied by Rindlav-Wetsling et al. (1998),

*To whom correspondence should be addressed 
Stading et al. (2001) and Bader and Göritz (1994a, 1994b). Changes in crystallinity and mechanical properties were measured as a function of amylose or amylopectin content, relative humidity (RH) and temperature. Several studies dealing with protein film drying can also be mentioned. Jangchud and Chinnan (1999) studied the effect of $\mathrm{pH}$ and drying temperature on peanut protein films. Working with whey protein films, Alcantara et al. (1998) verified an increase in coating strength and barrier properties at higher drying rates. Nevertheless, different results were found with gelatin film (Menegalli et al., 1999). Drying at high RH and temperature resulted in the melting of the gel and the appearance of phase separation as well as a decrease in drying rate.

Amaranth seeds contain a significant percentage of protein (14-17\%), fat (5-9\%) and starch $(62 \%)$, which make the flour a promising material for the production of films. Given the numerous mechanisms hypothesized to affect the properties of films of various types, the objective of this work was to study the effects of drying conditions and glycerol content on the mechanical properties of film produced with amaranth flour.

\section{MATERIALS AND METHODS}

\section{Raw Material and Chemical Analysis}

Amaranth flour was prepared from seeds of Amarantus caudatus, grown in Peru. The flour was obtained using a modification of the alkaline wet milling method of Perez, Bahnassey and Breene (1993), developed by Tapia-Blácido (2003). Glycerol and all chemicals were of reagent grade. The water, protein, ash and lipid contents of amaranth flour samples were analyzed according to the standard methods of the AOAC (1997). The amylose content was measured using the colorimetric method (Juliano, 1971), modified by Martinez and Cuevas (1989).

\section{Film Preparation and Characterization}

Films were made by the casting technique, which consists of drying a film-forming solution (FFS) after application on a support. Glycerol was used as plasticizer. The following procedure was developed: a water solution of $4 \%$ amaranth flour was homogenized in a mixer for $25 \mathrm{~min}$. The $\mathrm{pH}$ was then adjusted to 10 with $\mathrm{NaOH}(0.1 \mathrm{~N})$ to dissolve the protein. The solution was heated to the processing temperature $\left(85.0^{\circ} \mathrm{C}\right)$ with gentle stirring and plasticizer was added after $15 \mathrm{~min}$. For each film, $40 \pm 0.08 \mathrm{~g}$ of casting solution was poured onto acrylic plates $(9.2 \times 17.9 \mathrm{~cm})$ to obtain a constant thickness of $85 \pm 5 \mu \mathrm{m}$. These films were dried in a chamber with air circulation under controlled conditions of relative humidity (40,55 and 70\%) and temperature $\left(30,40,50^{\circ} \mathrm{C}\right)$. Drying curves for the solution were obtained with a differential microbalance (Dynamic Vapor Sorption Measurement Systems, United Kingdom) using a continuous flow of nitrogen. The equipment controlled the relative humidity with a precision of $1 \%$ and the temperature with a precision of $0.1^{\circ} \mathrm{C}$. The samples were dried on quartz plates $16.41 \mathrm{~mm}$ in diameter and films with a thickness of $48.97 \pm 0.34 \mu \mathrm{m}$ of were formed. The mass was measured as a function of drying time until the equilibrium moisture content was reached. The drying kinetics were measured at the same levels of temperature and $\mathrm{RH}$.

The thickness of the films was measured (average of eight measurements) with a digital micrometer (Fowler). For the mechanical tests, film samples were preconditioned and tested under the same controlled conditions of temperature and relative humidity $\left(25^{\circ} \mathrm{C}, \quad 58 \%\right)$. A TA XT2 (SMS) texturometer was used for puncture and tensile tests. The puncture test was conducted in accordance with the methodology of Gontard et al. (1994), while the tensile tests were performed according to the standard method D882-95 (ASTM, 1995).

\section{Experimental Design}

In this work the effects of glycerol content, relative humidity and drying temperature on mechanical properties measured by puncture and tensile tests were studied using a full factorial design $\left(2^{3}\right)$ with three measurements at the central point. Table 1 gives the values of the variables and coded levels. The statistical analysis of variance (ANOVA), multiple comparison tests and all other statistical analyses were performed using Statistica 5.0 software. Data were fitted to a first-order equation (Equation 1) as a function of dependent variables.

$$
\begin{aligned}
& Y_{i}=b_{0}+b_{1} X_{1}+b_{2} X_{2}+b_{3} X_{3}+b_{12} X_{1} X_{2}+ \\
& +b_{13} X_{1} X_{3}+b_{23} X_{2} X_{3}+b_{123} X_{1} X_{2} X_{3}
\end{aligned}
$$

where $b_{n}$ are constant regression coefficients, $Y_{i}$ are dependent variables (mechanical properties) and $X_{1}$, $\mathrm{X}_{2}$ and $\mathrm{X}_{3}$ are the coded independent variables (glycerol content, relative humidity and temperature 
of drying). The drying kinetics were measured for all levels of temperature $\left(30,40\right.$ and $\left.50^{\circ} \mathrm{C}\right)$ and relative humidity $(40,55$ and $70 \%)$.

\section{RESULTS}

\section{Material and Film Drying Characteristics}

The composition of the amaranth flour (dry basis) was $7.97 \% \pm 0.18$ water, $2.14 \% \pm 0.03$ ashes, $8.93 \% \pm 0.03$ lipids, $14.21 \% \pm 0.77$ protein and $74.7 \%$ starch $(7.58 \% \pm 0.40$ amylose and nearly $67 \%$ amylopectin). The films formed were light yellow and transparent with an average thickness of $85 \pm 5$ $\mu \mathrm{m}$.

Previous experimentation on drying conditions during film production had shown that the final moisture content must be fixed at a value of approximately $22 \%$ to assure that the film was easy to peel off the plates. At higher moisture contents, sticky films were obtained, whereas less moisture resulted in brittle ones. The final moisture content in starch films must be controlled so that its final temperature is not lower than the glass transition temperature.

\section{Full Experimental Design}

To evaluate the effect of drying conditions and glycerol content on the mechanical properties, the force (F) and \% deformation (D) at the break in puncture tests as well as the tensile strength (T), elongation (E) and Young modulus (YM) were measured as a function of glycerol content $(\mathrm{Cg})$, temperature $(\mathrm{Ts})$ and relative humidity $(\mathrm{RH})$. The results of the full experimental design and the value of the independent and coded variables are shown in Table 1.
For the dependent variable force at the break in the puncture test, two variables, glycerol content and temperature, as well as the interaction effects, $\mathrm{Cg}$ Ts and $\mathrm{Cg} \mathrm{RH}$, were found to be significant $(\mathrm{p} \leq 0.05)$ for the linear effects. The following polynomial equation (2) was fitted to the data $\left(R^{2}=0.96\right)$

$$
\begin{aligned}
& \mathrm{F}=0.988-0.440 \mathrm{Cg}+0.056 \mathrm{Ts}- \\
& -0.036 \mathrm{CgTs}+0.082 \mathrm{CgRH}
\end{aligned}
$$

Deformation in the puncture test was significantly effected not only by glycerol content and temperature, but also by relative humidity. Linear effects and significant interactions were $\mathrm{Cg} \mathrm{Ts}, \mathrm{Cg}$ $\mathrm{RH}$ and $\mathrm{Cg}$ Ts $\mathrm{RH}$. All effects were statistically significant $(\mathrm{p} \leq 0.05)$. The regression model was $\left(\mathrm{R}^{2}\right.$ $=0.94)$ :

$$
\begin{aligned}
& \mathrm{D}=27.68+6.38 \mathrm{Cg}-0.65 \mathrm{Ts}+0.55 \mathrm{RH}- \\
& -1.04 \mathrm{CgTs}-1.33 \mathrm{CgRH}+0.42 \mathrm{CgTsRH}
\end{aligned}
$$

The following coded model was obtained for tensile data $(\mathrm{p} \leq 0.05)$ with $\mathrm{R}^{2}=0.98$ :

$$
\begin{aligned}
& \mathrm{T}=0.665-0.273 \mathrm{Cg}+0.066 \mathrm{Ts}-0.088 \mathrm{RH}+ \\
& +0.097 \mathrm{CgRH}+0.066 \mathrm{TsRH}-0.091 \mathrm{CgTsRH} \\
& \mathrm{E}=118.56+14.18 \mathrm{Cg}+4.50 \mathrm{Ts}+\quad\left(\mathrm{R}^{2}=0.96\right) \\
& +9.64 \mathrm{RH}+11.65 \mathrm{CgTs} \\
& \mathrm{YM}=3.60-3.66 \mathrm{Cg}+0.66 \mathrm{Ts}- \\
& -2.06 \mathrm{RH}-0.66 \mathrm{CgTs}+ \\
& +2.19 \mathrm{CgRH}+0.21 \mathrm{TsRH}
\end{aligned}
$$

\begin{tabular}{|c|c|c|c|c|c|c|c|c|}
\hline \multirow[b]{2}{*}{ Test } & \multirow[b]{2}{*}{$\operatorname{Cg}\left(X_{1}\right)$} & \multirow[b]{2}{*}{$\operatorname{Ts}\left(X_{2}\right)$} & \multirow[b]{2}{*}{$\mathbf{R H}\left(\mathbf{X}_{3}\right)$} & \multicolumn{2}{|c|}{ Puncture test } & \multicolumn{3}{|c|}{ Tensile test } \\
\hline & & & & $\begin{array}{l}\text { Force } \\
\text { (N) }\end{array}$ & $\begin{array}{c}\text { Deformation } \\
\text { (\%) }\end{array}$ & $\begin{array}{c}\text { Strength } \\
\text { (MPa) }\end{array}$ & Elongation (\%) & $\begin{array}{l}\text { Young modulus } \\
\text { (MPa) }\end{array}$ \\
\hline 1 & $40(+1)$ & $50(+1)$ & $70(+1)$ & 0.73 & 31.08 & 0.47 & 144.42 & 0.91 \\
\hline 2 & $40(+1)$ & $50(+1)$ & $40(-1)$ & 0.50 & 31.95 & 0.50 & 156.57 & 0.52 \\
\hline 3 & $40(+1)$ & $30(-1)$ & $70(+1)$ & 0.65 & 33.80 & 0.38 & 127.48 & 0.78 \\
\hline 4 & $40(+1)$ & $30(-1)$ & $40(1)$ & 0.50 & 36.04 & 0.31 & 108.73 & 0.63 \\
\hline 5 & $30(-1)$ & $50(+1)$ & $70(+1)$ & 1.53 & 22.24 & 1.00 & 113.28 & 5.46 \\
\hline 6 & $30(-1)$ & $50(+1)$ & $40(-1)$ & 1.60 & 19.45 & 1.05 & 84.20 & 13.24 \\
\hline 7 & $30(-1)$ & $30(-1)$ & $70(+1)$ & 1.28 & 22.45 & 0.55 & 121.51 & 2.10 \\
\hline 8 & $30(-1)$ & $30(-1)$ & $40(-1)$ & 1.49 & 17.71 & 1.24 & 104.56 & 11.33 \\
\hline 9 & $35(0)$ & $40(0)$ & $55(0)$ & 0.85 & 30.05 & 0.63 & 117.40 & 1.65 \\
\hline 10 & $35(0)$ & $40(0)$ & $55(0)$ & 0.89 & 29.69 & 0.60 & 114.87 & 1.45 \\
\hline 11 & $35(0)$ & $40(0)$ & $55(0)$ & 0.87 & 29.99 & 0.60 & 111.37 & 1.48 \\
\hline
\end{tabular}

Table 1: Full factorial design. Variable values (coded levels) and results $\left(2^{3}\right)$ 


\section{Effect of Glycerol Content and Drying Conditions on Mechanical Properties}

Response surfaces generated from equations (4) to (6) are shown in Figures 1 to 6 . These contain the results of the tensile tests; those of the puncture tests have similar tendencies and are not shown. As usual, tensile strength decreased as a function of glycerol content as a consequence of glycerol's plasticizing effect (Figures 1 and 2).

The influence of drying conditions are better observed at a low glycerol content (Figures 3 and 4). It can be verified that the highest value for tensile strength at the break is for the lowest temperature of air drying $\left(30^{\circ} \mathrm{C}\right)$ and the lowest $\mathrm{RH}(40 \%)$. Moreover, tensile strength is a strong function of

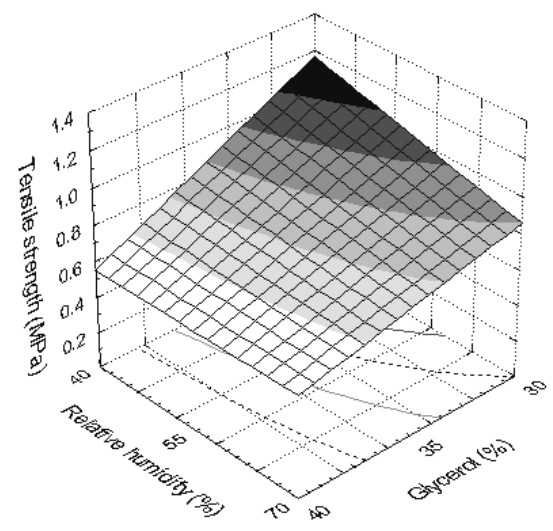

Figure 1: Tensile strength as a function of relative humidity and glycerol content. $\mathrm{Ts}=40^{\circ} \mathrm{C}$

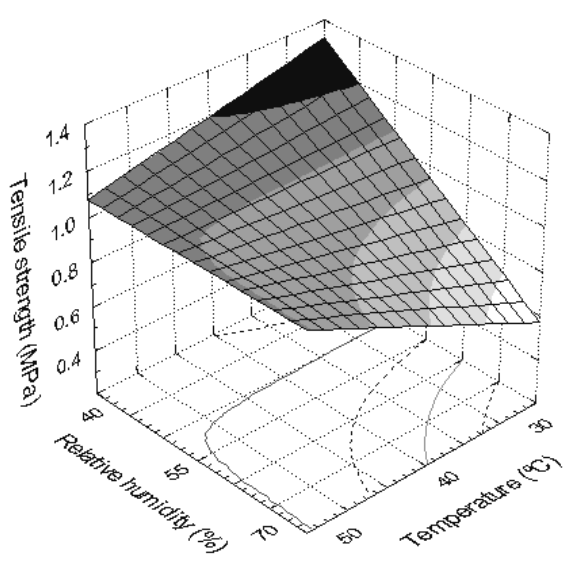

Figure 3: Tensile strength as a function of relative humidity and temperature.

$$
\mathrm{Cg}=30 \%
$$

relative humidity at low temperatures, decreasing with the increase in $\mathrm{RH}$. Tensile elongation at the break shows a slightly different pattern, increasing with higher relative humidities and lower temperatures.

Tensile strength and elongation at the break are a measure of the real resistance of films and plasticization for practical uses. A better diagnosis of film structure can be obtained from examination of the Young Modulus. This modulus is measured in the linear region of response where no irreversible changes in structure can be found. In amaranth flour films, the relative humidity (Figure 5) exerts a pronounced effect for 30\% glycerol. Higher Young Modulus values (stiffer films) were obtained, at high temperatures and low RHs (Figure 6). This correlates with higher drying rates.

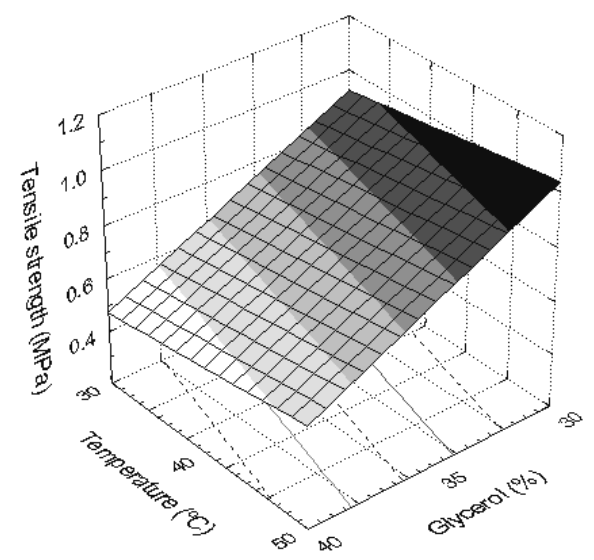

Figure 2: Tensile strength as a function of temperature and glycerol content. $\mathrm{RH}=55 \%$

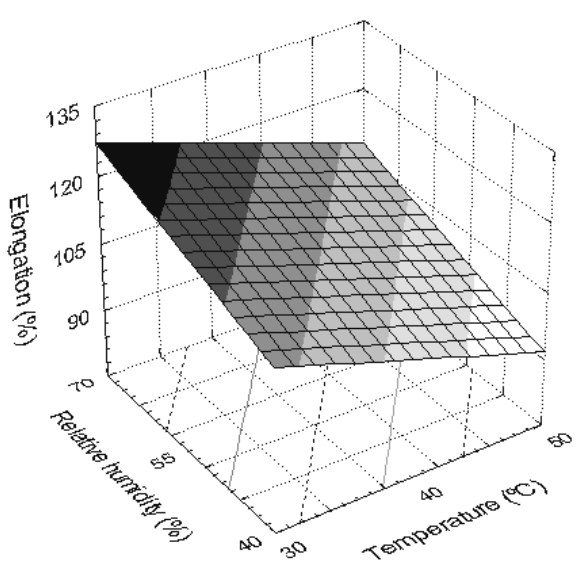

Figure 4: Tensile elongation as a function of relative humidity and temperature.

$\mathrm{Cg}=30 \%$ 


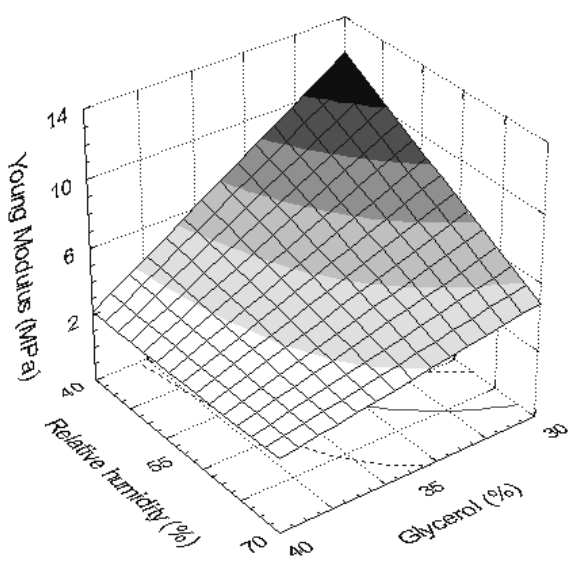

Figure 5: Young Modulus as a function of relative humidity and glycerol content. $\mathrm{Ts}=40^{\circ} \mathrm{C}$

To explain these results it must be remembered that amaranth flour films, plasticized with $30 \%$ glycerol, are a mixture of $51 \%(\mathrm{~g} / \mathrm{g}$ dry film) amylopectin, 5.8\% amylose, $6.8 \%$ lipids, $10.9 \%$ protein and $23 \%$ glycerol. The main structure of the film must be attributed to the network of amylose and protein forming a continuous phase where amylopectin is assumed to be distributed as a filler throughout the network (Carnali and Zhou, 1996). Amylose, a linear D-glucan polymer, forms a gel that, it has been suggested, contains rigid, crystalline, double helicoidal junction zones connected by more mobile amorphous zones (Rindlav-Westling et al., 1998). Lipids are assumed to form a complex with amylose (Bader and Göritz, 1994a) and as well act as plasticizers (Tapia-Blácido, 2003).

These various biopolymers may behave in different ways depending on the drying conditions. During drying as evaporation occurs up to the final moisture content, the solution is maintained at a temperature that depends on heat and mass transfer, air temperature and RH. The time span in drying always depends on RH and air temperature. Several changes in polymer phase may occur. The stressstrain curves for high-amylose native corn starch films (55\% amylose, $1.4-1.5 \%$ native lipids) without plasticizers depict stress-strain as a function of the drying temperature and the presence of lipids, especially at lower water contents. At higher water contents, the plasticizing effect of water inhibits this effect (Bader and Göritz, 1994a, 1994b). The results of $\mathrm{x}$-ray scattering show a continuous transformation from B-type crystallites in films dried at $20^{\circ} \mathrm{C}$ to the denser crystalline structure of the A type at higher

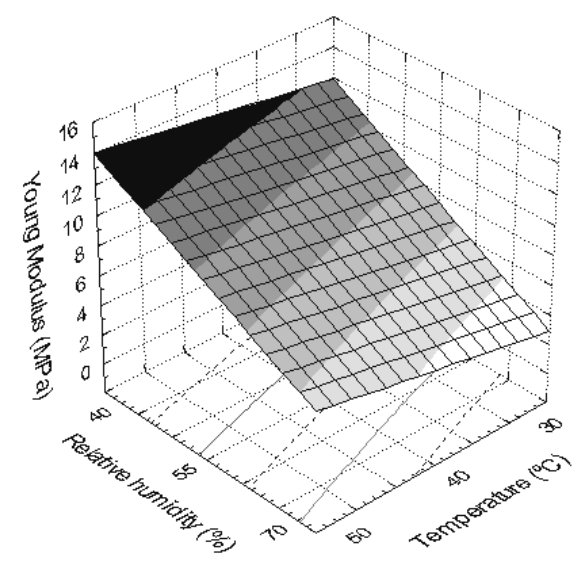

Figure 6: Young Modulus as a function of relative humidity and temperature. $\mathrm{Cg}=30 \%$

temperatures. A V type is also suggested when an amylose-lipid complex is formed at $80^{\circ} \mathrm{C}$. When drying at $60^{\circ} \mathrm{C}$, the highest values of stress and elongation at the break are obtained, but at higher temperatures a more brittle material is obtained.

As observed by Rindlav-Westling et al. (1998) and Stading et al. (2001), during drying at $23^{\circ} \mathrm{C}$, the crystallinity of amylose films changed slightly, whereas the crystallinity of amylopectin films experienced a sharp increase as a function of RH as higher relative humidities imply longer drying times. The tensile stress of amylopectin film depends on crystallinity, so a continuous increase in RH will be accompanied by a decrease in elongation.

In amylose films the tensile stress and Young Modulus decrease and tensile deformation increases with RH up to $70 \%$; then all tendencies are reversed. Since RH did not affect the crystallinity of amylose films, the changes in mechanical strength observed probably depend on the macrostructure formed. This fact was verified using TEM micrographs, which linked the use of a higher $\mathrm{RH}$ during film formation with an alteration in the pore size distribution as well as nonhomogeneity of the amylose network (Standing et al., 2001). Amylose, however, forms homogenous films at $20 \% \mathrm{RH}$, but with an increase in $\mathrm{RH}$ denser polymer zones with larger pores were observed. A maximum value for porosity was reached at $70 \% \mathrm{RH}$, although, denser films were obtained when RH increased up to $90 \%$.

The behavior of various protein films has also been studied. For gluten films, Kayserilioğlu et al. (2003) found changes in tensile strength and elongation as a function of temperature and $\mathrm{RH}$. 
Denser and more nonhomogeneous structures in SEM images were observed at high drying rates (high temperature and low RH). Whey protein films also showed higher tensile strength and lower elongation at the break when higher drying rates were used (Alcantara et al., 1998), and similar results were found by Jangchud and Chinnan (1999) with peanut protein film. Only two extreme drying conditions were used $\left(95^{\circ} \mathrm{C}\right.$ and $30 \% \mathrm{RH}$ and $21^{\circ} \mathrm{C}$ and $50 \%$ ) and the improvement in properties of tensile strength, elongation and permeability with the more severe air-drying conditions, was to be expected as no previous heat protein treatment had been conducted in that work. Consequently, as temperature increases heat denaturation of protein is expected, but always with an increase in film shrinkage.

The drying kinetics was measured in a differential microbalance as a function of time, $\mathrm{RH}$ and temperature. The decrease in moisture content can be seen in Figure 7. For all conditions a long period with a constant drying rate is verified. The usual trend of higher drying rates as a function of increasing temperature and decreasing $\mathrm{RH}$ are found. In Table 2, the time required to achieve the final moisture content under the different drying conditions, final water content and film temperature during the constant drying period are shown. There is an unexpected finding when final moisture contents are examined.

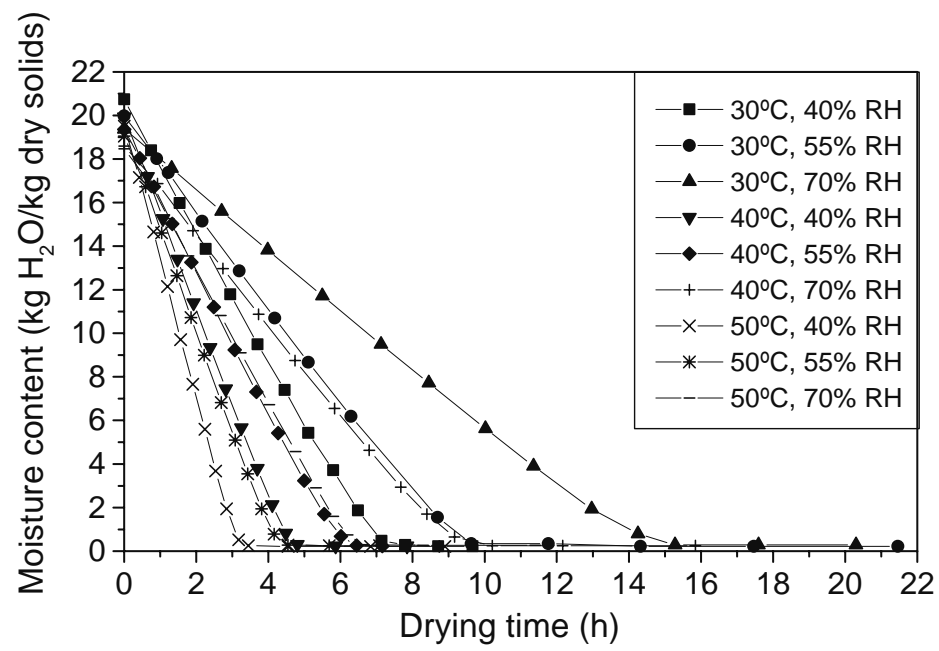

Figure 7: Moisture content as a function of drying time, temperature and relative humidity $(\mathrm{Cg}=22.5 \%)$

These moisture contents were measured until no change in total mass was detected in the balance so that they might be considered to be the thermodynamic equilibrium moisture contents. Nevertheless, the increase in final moisture contents with air temperature is not in agreement with equilibrium data. This anomalous behavior has been reported in the drying of polymeric suspensions and is known as trapping skinning, where the residual moisture content increases at high drying gas flow rate and temperature. This is found in the drying of polymer coatings when stresses develop due to shrinkage. It has been suggested that the stress gradients contribute to solvent mass transport, so that non-Fickian transport appears. When stress relaxation occurs, negative non-Fickian flux causes a thin layer of low solvent concentration to form near the coating surface with a thicker layer of high solvent concentration within the coating (Vinjamur and
Cairncross, 2002, 2003).

The highest values of Young Modulus (Figure 6) were measured at $40 \% \mathrm{RH}$, which corresponds to the highest drying rates with the highest value at the lowest temperature. As these conditions correspond to a short drying time $(7.4 \mathrm{~h})$ and low film temperature $\left(22^{\circ} \mathrm{C}\right)$, no changes in cristallinity or further denaturation of protein could explain these results. However, these conditions are related to a small occurrence of trapping and more homogeneous film structures. For tensile strength at the break, the highest values were also obtained at $30^{\circ} \mathrm{C}$ and $40 \%$ $\mathrm{RH}$, whereas the highest value of tensile deformation was obtained at $30^{\circ} \mathrm{C}$ but at the highest RH of $70 \%$, which corresponds to a nontrapping situation but a longer drying time, which allows better conditions of temperature and moisture content for occurrence of polymer entanglements. 
Table 2: Drying time and final equilibrium moisture content

\begin{tabular}{|c|c|c|c|c|}
\hline $\begin{array}{c}\text { Air temperature } \\
\mathbf{(} \mathbf{0} \mathbf{C})\end{array}$ & $\begin{array}{c}\text { Relative humidity } \\
\mathbf{( \% )}\end{array}$ & $\begin{array}{c}\text { Drying time } \\
\mathbf{( h )}\end{array}$ & $\begin{array}{c}\text { Final moisture } \\
\text { content (d.b.) }\end{array}$ & $\begin{array}{c}\text { Wet bulb } \\
\text { temperature }\left(\mathbf{(}^{\mathbf{0}} \mathbf{C}\right)\end{array}$ \\
\hline 30 & 40 & 7.4 & 0.1645 & 22 \\
30 & 55 & 11.5 & 0.2026 & 23 \\
30 & 70 & 19.1 & 0.2703 & 26 \\
40 & 40 & 5.0 & 0.1932 & 28 \\
40 & 55 & 9.1 & 0.2247 & 31.3 \\
40 & 70 & 17.2 & 0.3035 & 34.5 \\
50 & 40 & 4.7 & 0.2256 & 35.4 \\
50 & 55 & 6.2 & 0.2571 & 38.6 \\
50 & 70 & 7.5 & 0.3270 & 43.6 \\
\hline
\end{tabular}

\section{CONCLUSIONS}

During the drying of film-forming solution due to its complex composition (biopolymers, solvents and lipids) several phenomena may occur and influence the structure and mechanical properties, changes in the microstructure or large-scale changes in the macrostructure, influencing the entire network. In amaranth flour film, the mechanical properties seem to depend more on changes in the macrostructure.

\section{ACKNOWLEDGMENTS}

The authors wish to thank FAPESP (process number 02/13045-8) and CAPES (Brazilian Government) for the financial support provided.

\section{NOMENCLATURE}

$\begin{array}{ll}\text { Cg } & \text { Glycerol content } \\ \text { D } & \begin{array}{l}\text { Deformation at the break } \\ \text { in puncture test }\end{array} \\ \text { E } & \begin{array}{l}\text { Elongation } \\ \text { F }\end{array} \\ & \begin{array}{l}\text { Force at the break in } \\ \text { puncture test }\end{array} \\ \text { T } & \text { Tensile strength } \\ \text { RH } & \text { Relative humidity } \\ \text { Ts } & \text { Drying temperature } \\ \text { YM } & \text { Young modulus }\end{array}$

(g glycerol/100 g amaranth flour)

$(\mathrm{MPa})$

\section{REFERENCES}

Alcantara C.R., Rumsey, T.R. and Krochta, J.M., Drying Rate Effect on the Properties of Whey Protein Films, Journal of Food Process Engineering, vol. 21, pp. 387-405 (1998).
AOAC, Official Methods of Analysis, $16^{\text {th }}$ Edition. Washington: Association of Official Analytical Chemists (1997).

ASTM, American Society for Testing and Materials, Annual Book of ASTM Standards, Philadelphia (1995).

Bader, H.G. and Göritz, D., Investigation on High Amylose Corn Starch Films. Part 1: Wide Angle X-ray Scattering (WAXS), Starch/Stärke, vol. 46, no. 6, pp. 229-232 (1994a).

Bader, H.G. and Göritz, D., Investigation on High Amylose Corn Starch. Part 3: Stress Strain Behavior, Starch/Stärke, vol. 46, no. 11, pp. 435439 (1994b).

Carnali J.O., Zhou, Y., An Examination of the Composite Model for Starch Gels, Journal of Rheology, vol. 40, no. 2, pp. 221-234 (1996).

Gontard, N., Duchez, C., Cuq, J.L. and Guilbert, S., Edible Composite Films of Wheat Gluten and Lipids-Water-vapor Permeability and Other Physical Properties, International Journal of Food Science and Technology, vol. 29, no. 1, pp. 39-50 (1994).

Jangchud A. and Chinnan, M.S., Peanut Protein Film as Affected by Drying Temperature and $\mathrm{pH}$ of Film Forming Solution, Journal of Food Science, vol. 64, no. 1, pp. 153-157 (1999).

Juliano, B.O., A Simplified Assay for Milled-rice Amylose, Cereal Science Today, vol. 6, pp. 334340 (1971).

Kayserilioğlu, B.Ş., Bakir, U., Yilmaz, L. and Akkaş, N., Drying temperature effects on wheat gluten film properties, Journal of Agricultural and Food Chemistry, vol. 51, pp. 964-969 (2003).

Martinez, C. and Cuevas, F., Evaluation of the Culinaria and Molinaria Quality of the Rice, Guide of estudo, Cali, CIAT, 75 p. (1989).

Menegalli, F.C., Sobral, P.J., Roques, M.A. and Laurent, S., Characteristics of Gelatin Biofilms in Relation to Drying Process Conditions near 
Melting, Drying Technology, vol. 17, nos. 7 and 8, 1697-1706 (1999).

Perez, E., Bahnassey, Y.A. and Breene, W.M., A Simple Laboratory Scale Method for Isolation of Amaranth Starch, Starch/Stärke, vol. 45, pp. 211214 (1993).

Rindlav-Wetsling, A., Standing, M., Hermansson, A. and Gatenholm, P., Structure, Mechanical and Barrier Properties of Amylose and Amylopectin Films, Carbohydrate Polymers, vol. 36, pp. 217224 (1998).

Stading, M., Rindlav-Westling, A. and Gatenholm P., Humidity-induced Structural Transitions in
Amylose and Amylopectin Films, Carbohydrate Polymer, vol. 45, pp. 209-217 (2001).

Tapia-Blácido, D., Preparation and Characterization of Amaranth Flour Biofilms, Master's thesis, Unicamp, Brazil (2003).

Vinjamur, M. and Cairncross, R.A., Guidelines for Dryer Design Based on Results from Non-Fickian Model, Journal Applied Polymer Science, vol. 87, no. 3, pp. 477-486 (2003).

Vinjamur, M. and Cairncross, R.A., Non-Fickian Nonisothermal Model for Drying of Polymer Coatings, AICHE Journal, vol. 48, no. 11, pp. 2444-2458 (2002). 